\title{
Common peroneal nerve schwannoma: an unusual differential for a symptomatic knee lump
}

\author{
Omair Shariq, Sarkhell Radha, Sujith Konan \\ Department of Trauma and Orthopaedic Surgery, Chelsea and Westminster Hospital, London, UK
}

\section{DESCRIPTION}

A 60-year-old woman with no medical history presented to the emergency department with worsening knee pain after a short-haul flight. She had a 2 year history of intermittent left knee pain, made worse by crouching and a lump at the back of her leg, which was gradually increasing in size. On examination, she was found to have a $3 \times 4 \mathrm{~cm}$ lump behind the posterolateral aspect of the left knee. The lump was located in the subcutaneous plane, firm in consistency, deep to the fascia and was mobile in the horizontal plane. It did not transilluminate and was not fluctuant. No other lumps were palpable and there were no distal neurological signs. Her investigations including blood results, D-dimer and venous ultrasound were unremarkable. An MRI (figure 1) showed a welldefined mass posterior to the fibular head, arising from the common peroneal nerve, representing a schwannoma.
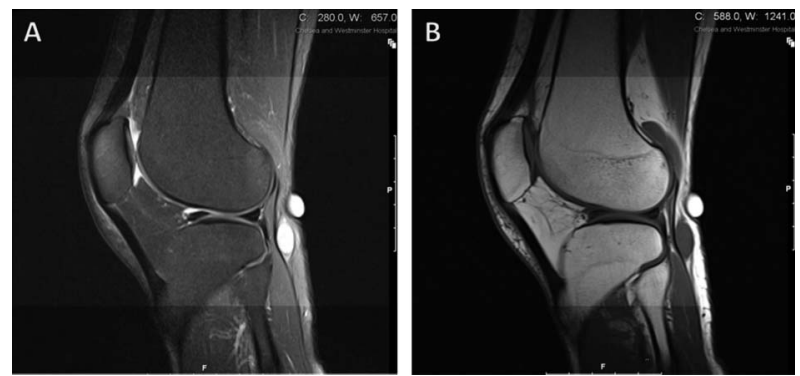

Figure 1 T2-weighted (A) and T1-weighted (B) MRI showing a well-defined ovoid mass posterior to the fibula head (measuring up to $15 \mathrm{~mm}$ in long axis), which arises eccentrically from and cannot be separated from, the underlying common peroneal nerve.
The patient was referred to a specialist peripheral nerve injury unit and underwent intralesional excision.

Schwannomas, or neurilemmomas, are the commonest benign peripheral nerve sheath tumours. ${ }^{1}$ However, reports of schwannomas arising from the common peroneal nerve are exceptionally rare. ${ }^{2}$ While usually clinically silent, this case highlights how they can become symptomatic due to mechanical compression and may present with pain, swelling or a lump. A thorough examination and prompt investigation helped to make a timely diagnosis and initiate appropriate treatment. Schwannomas should be included in the differential diagnosis of lumps in the vicinity of nerves.

\section{Learning points}

- Recall the importance of conducting a thorough physical examination and performing appropriate investigations for patients with a painful knee lump.

- Schwannomas should be included in the differential diagnoses for a soft tissue mass of the lower limb and knee pain.

- MRI is the imaging modality of choice for diagnosis of schwannoma.

Competing interests None

Patient consent Obtained.

\section{REFERENCES}

1. Russell RC, Williams NS, Bulstrode CJ. Bailey and Love's short practice of surgery, 24th edn. London: Arnold.

2. Houshian S, Freund KG. Gigantic benign schwannoma in the lateral peroneal nerve. Am J Knee Surg 1999;12:41-2. 


\section{BMJ Case Reports}

Copyright 2012 BMJ Publishing Group. All rights reserved. For permission to reuse any of this content visit http://group.bmj.com/group/rights-licensing/permissions.

BMJ Case Report Fellows may re-use this article for personal use and teaching without any further permission.

Please cite this article as follows (you will need to access the article online to obtain the date of publication).

Shariq 0, Radha S, Konan S. Common peroneal nerve schwannoma: an unusual differential for a symptomatic knee lump. BMJ Case Reports 2012; 10.1136/bcr-2012-007346, Published XXX

Become a Fellow of BMJ Case Reports today and you can:

- Submit as many cases as you like

- Enjoy fast sympathetic peer review and rapid publication of accepted articles

- Access all the published articles

- Re-use any of the published material for personal use and teaching without further permission

For information on Institutional Fellowships contact consortiasales@bmjgroup.com

Visit casereports.bmj.com for more articles like this and to become a Fellow 